\title{
Production Bacteriosin by Rhizobia obtained from Root nodules of Macrotyloma uniflorum (Lam.) Verdc. (Horse Gram)
}

\author{
Prabhavati Edulamudi*1, Anthony Johnson Antony Masilamani², Venkata Ramana Sai Gopal Divi² and \\ Veera Mallaiah Konada ${ }^{1}$ \\ ${ }^{I}$ Prabhavati Edulamudi and Veera Mallaiah Konada, Department of Botany and Microbiology, Acharya Nagarjuna University, Nagarjuna Nagar, \\ Guntur (Dt.) - 522510, Andhra Pradesh, India. ${ }^{2}$ Anthony Johnson Antony Masilamani and Venkata Ramana Sai Gopal Divi, Department of Virology, \\ Sri Venkateswara University, Tirupati, India.
}

(Received 10 September 2011; Accepted 03 December 2011)

\begin{abstract}
Thirty two Rhizobium isolates obtained from the root nodules of Horse gram plants grown in 32 different soil samples collected from various regions in Andhra Pradesh, India. They were identified as rhizobia by nodulation test. These isolates were used to study the production of bacteriocins. All the isolates produced bacteriocins against the remaining isolates. The isolates HGR-4 and 9 showed maximum activity/inhibition zone among all the isolates, and also found to be inhibiting more number of isolates than that of other bacteriocin producing isolates. The bacteriocin protein substance produced by the isolates HGR-4 and 9 showed a molecular weight of $\sim 50 \mathrm{kDa}$ by SDS-AGE and bacteriocin plasmids molecular weight is $>22 \mathrm{~kb}$ and $>24$ kb.
\end{abstract}

Key words: bacteriocin, rhizobia, competition.

\section{Introduction}

The Rhizobium legume symbiosis is the most promising plant bacterium association so far known. Inoculated Rhizobium strains often fail to compete with the indigenous soil rhizobia and do not increase nodulation ${ }^{1,2}$. Thus the successful use of rhizobial inoculants requires the knowledge of factors affecting the effectiveness and competitive ability of the rhizobia. One of the major factors reported to be affecting competition among rhizobia are bacteriocins $\mathrm{s}^{3-5}$. Bacteriocins are proteins or protein complexes with bacteriocidal activity against usually closely related to producer bacterium ${ }^{6}$. Bacteriocins are ribosomally encoded peptide antibiotics produced by both Gram negative and Gram positive bacteria. Bacteriocins produced by the Gram negative are well studied. Rhizobium leguminosarum has been shown to produce bacteriocins which have been characterized small, medium or large based on their assumed size characteristics ${ }^{7,8}$. Small bacteriocins were found to be chloroform soluble and have molecular mass less than $2000 \mathrm{Da}^{7,9}$. Oresnik et al. ${ }^{5}$ found that the bacteriocins appear to play a major role in determining competitiveness for nodulation when assayed against some strains.

Genetic evidence suggests that some of the genes involved in Rhizobium-legume symbiosis may be located on plasmids ${ }^{10-12}$. Many bacteriocins of enterobacteria are plasmid determined ${ }^{13}$ and this may be a feature common to other bacterial genera. Bacteriocin production by Rhizobium spp. has been described ${ }^{4,14-16}$ but, there are no data to suggest that it may be plasmid determined.

So the successful preparation of mixed inoculum requires the knowledge of bacteriocin producing ability of the inocula strains as well as their effect on the related rhizobia. In the present study 32 rhizobia isolated from various regions in Andhra Pradesh, India has been investigated for their bacteriocin production.

\section{Materials and Methods}

Isolation of root nodulating bacteria from horse gram

Root nodules were collected from the horse gram plants. Rhizobia were isolated from fresh nodules by the standard method on Yeast Extract Mannitol Agar (YEMA) medium ${ }^{17}$. They were designated as HGR-1 (Horse Gram Rhizobia) to HGR-32. Root nodulating ability of these isolates was determined by nodulation test ${ }^{18}$. Morphological, cultural and biochemical activities of the isolates were studied using standard methods. Four strains such as HGR-4, 6, 13, and 25 were selected for 16S rRNA sequence and were submitted to the NCBI GenBank under the accession numbers GQ483457, GQ483458, GQ483459 and GQ483460.

\section{Bacteriocin Activity Assay}

The bacteriocin producing ability of the strains was bioassayed by simultaneous antagonism method ${ }^{6}$. Bacteriocin activity was examined by adding $1 \mathrm{ml}$ of each diluted, sterile filtered sample on to the wells made on Tryptone Yeast extract (TY) medium ( $0.6 \%$ 
$\mathrm{w} / \mathrm{v}$ agar) seeded with $\log$ phase indicator strains $(0.5 \mu \mathrm{L}$ of the medium). Activity was quantified by two fold serial dilution 19 and is expressed in arbitrary units $\mathrm{mL}^{-1}\left(\mathrm{AU} \mathrm{mL}^{-1}\right)$.

\section{Bacteriocin protein purification}

Purification of proteins was carried out using the procedure of Yang et $a l .{ }^{20}$. Cell Free Supernatant (CFS) was used to carry out protein extractions. Twenty percent chloroform was added to the CFS in a separatory funnel. The aqueous phase formed was separated and used for precipitating out the proteins. Protein precipitation was carried out on ice or at $4^{\circ} \mathrm{C}$ by the addition of analytical grade ammonium sulphate. The aqueous phase was saturated with cold ammonium sulphate from 20 to $80 \%$ (w/v) saturations and gradually stirred with a glass stirrer for 10-15 min. The aqueous phase was kept overnight at $4^{\circ} \mathrm{C}$.

The precipitate was collected by centrifugation at $15000 \mathrm{xg}$ for 20 min. The solid pellet dissolved in distilled water and dialyzed against distilled water at room temperature for $24 \mathrm{~h}$. The suspension obtained was designated as proteinaceous fraction or crude bacteriocin fraction. All the different dialysates obtained were lyophilized. Lyophilized material of $0.01 \mathrm{~g}$ was added in $100 \mathrm{ml}$ Tris- $\mathrm{HCl}$ ( $\mathrm{pH} 6.5$ ) buffer and tested for inhibitory activity. The quantification of protein concentration was done by standard Bradford method ${ }^{21}$. Bovine serum albumin (BSA) was used to construct the standard curve.

\section{Bacteriocin protein purification}

Analysis of total cellular proteins of rhizobia was carried out by SDS-PAGE described by Laemmli ${ }^{22}$ with slight modifications. 3 $\mathrm{ml}$ of YEM broth was inoculated and incubated for $12 \mathrm{~h}$ at room temperature. It was centrifuged at $10000 \mathrm{~g}$ for $4 \mathrm{~min}$ at $4^{\circ} \mathrm{C}$. To the pellet sample buffer was added at 1:1 ratio. The samples were lysed by heating at $95^{\circ} \mathrm{C}$ for $2 \mathrm{~min}$ and immediately transferred to the cold water. Lysed samples and marker protein samples were loaded into the different gel slots. Electrophoresis was carried out at $100 \mathrm{~V}$ for $4 \mathrm{~h}$ at room temperature. The gel was stained with coomassie blue (Sigma). The image was photographed using Gel documentation unit (Alpha Innotech, USA).

\section{Plasmid analysis}

An overnight culture of rhizobia in YEM broth was centrifuged at $14000 \mathrm{xg}$, for $4 \mathrm{~min}$ at $4^{\circ} \mathrm{C}$ and the plasmid isolation and the analysis was carried out according to Sambrook and Russell ${ }^{23}$.

\section{Results and Discussion}

The cells are Gram negative rods, colonies are small, white on YEMA medium at room temperature. The optimum $\mathrm{pH}$ was in the range of 7-7.5. These strains grow at a temperature between 10 to $40^{\circ} \mathrm{C}$. Lower concentrations of $\mathrm{NaCl}$ favoured growth of these rhizobia. All the isolates were resistant to ampicillin and rifampicin. The isolates HGR-11, 22 and 23 showed resistance to most of the antibiotics tested, where as the isolate HGR-4 showed susceptibility towards most of the antibiotics.
Plasmid profile analysis is a useful tool for differentiating among strains of Rhizobium within the same species. The objective of this study is to determine the diversity in plasmid profiles and relationships between the isolates collected from the horse gram plants grown in 32 soil samples collected from various regions in Andhra Pradesh, India.

For comparative taxonomical identification the sequences of the four strains were submitted to the Ribosomal Database Project (RDP). According to NCBI and RDP first isolate (HGR-4) belongs to the genus Rhizobium, second one (HGR-6) is an unclassified member of Rhizobiaceae, third isolate (HGR-13) belongs to the genus Rhizobium and fourth isolate (HGR-25) belongs to the genus Caulobacter of the family Caulobacteriaceae in the order Caulobacterales of Alphaproteobacteria. It clearly shows that the horse gram rhizobia are phylogenetically distinct.

The production of bacteriocins is an advantageous character for strain competition ${ }^{24}$. Bacteriocin production was indicated by the formation of clear zones around the colonies. All the thirty two isolates produced clear zones on YEMA medium $(0.6 \% \mathrm{w} / \mathrm{v})$ inoculated with the isolates from the same host. No test strains inhibited its own growth, which is characteristic of bacteriocin producers 13,25 .

The bacteriocin production started after $48 \mathrm{~h}$ and reached maximum after $72 \mathrm{~h}$ of incubation. Further incubation does not affect the zone size, therefore, $72 \mathrm{~h}$ of growth of the producer colonies at $30^{\circ} \mathrm{C}$ was considered as optimum conditions for bacteriocin production in this study. That the production of bacteriocin is closely related with bacterial growth of producing organism and bacteriocin activity decreases more or less sharply at the end of the growth phase as a result of degradation by proteases was reported earlier in Micrococcus sp. ${ }^{26}$. All the strains of Rhizobium were found to produce antimicrobial activity, which inhibited the growth of the related strains on the agar medium.

In the present study maximum activity/inhibition zone was observed with the isolate HGR-9 and the isolate HGR-4 was also found to be inhibiting more number of isolates than that of other bacteriocin producing isolates, further studies were carried out with these two strains (Table1). Thus the activity spectrum varied from strain to strain was reported earlier in Rhizobium leguminosarum bv. viciae. This is consistent with the earlier report that the strains of Rhizobium leguminosarum bv. viciae differ in their activity spectrum ${ }^{27}$.

Present results showed that when the sample is successfully diluted, inhibition zone decreased until critical dilution was achieved, where no inhibition of the sensitive organism was observed. When the purified bacteriocin was tested against indicator strains, it showed highest activity at 50\% ammonium sulphate saturated pellet. The activity does not depend on the quantity of the protein produced.

SDS-PAGE analysis of protein isolated from the strain HGR-4 and 9 showed the presence of $\sim 50 \mathrm{kDa}$ protein band (Fig 1). Plasmid analysis of this strains showed that it contains two plasmids similar to $>22 \mathrm{~kb}$ and $24 \mathrm{~kb}$ (Fig 2). 
Production Bacteriosin by Rhizobia obtained from Root nodules of Macrotyloma

Table.1. Purification of isolated bacteriocin protein from HGR-4 and HGR-9

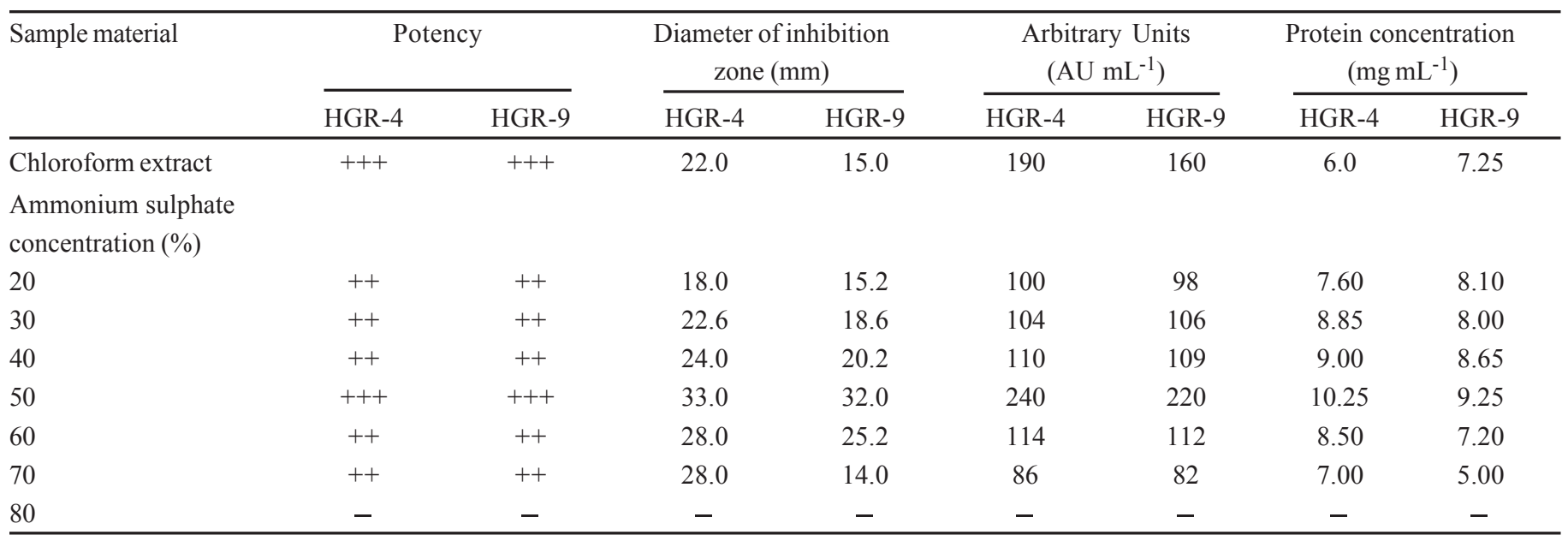

-: Ineffective, +: less effective, ++: Moderately effective, +++: Highly effective. All the results are means of triplicates.

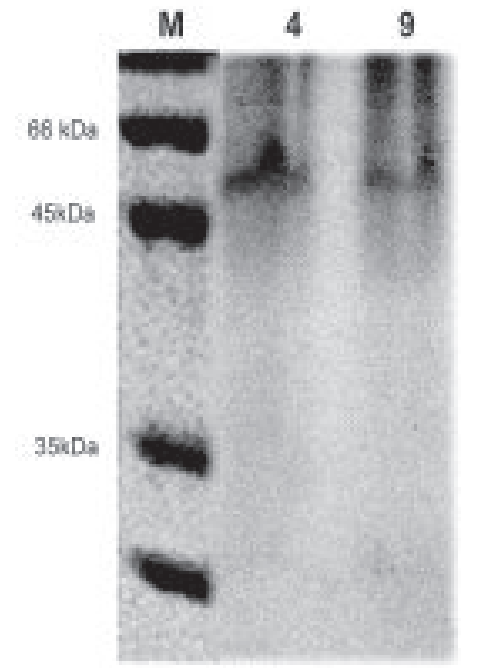

(M) Marker lane (4) Isolate HGR-4 (9) Isolate HGR-9

Fig 1. SDS-PAGE of purified bacteriocin of rhizobia from horse gram.

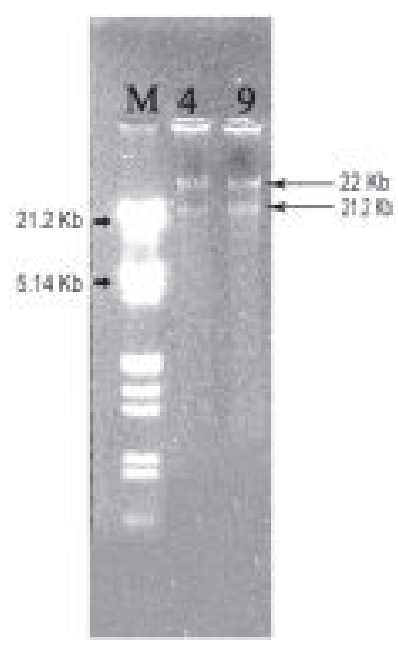

(M) Marker lane (4) Isolate HGR-4 (9) Isolate HGR-9

Fig 2. Bacteriocin plasmids of horse gram rhizobia
A characteristic large plasmid ( $\sim 4,000 \mathrm{bp}$ ) was present in thirteen isolates (HGR-2,3,4,5,6,10,11,12,14,20,22,24 and 26). Plasmid profile analysis of these isolates showed that these horse gram rhizobia showed similarity in their plasmid profiles although the rhizobia were isolated from different regions in Andhra Pradesh. Among the thirty two rhizobia, 13 isolates contained only one single plasmid i.e. $\sim 4000 \mathrm{bp}$, the remaining isolates had no plasmid. According to the size and number of plasmids (plasmid profile) it was possible to classify these 32 horse gram rhizobia into two groups and suggests that the isolates are genetically different (Fig 3).

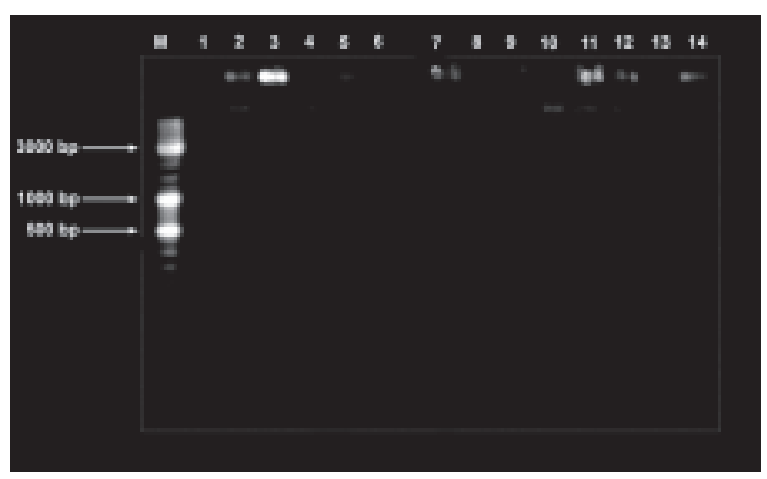

Figure 3. M- Marker Lane: Gene Ruler DNA Ladder Mix (Fermentas, USA)

Thus, these studies indicate that bacteriocin production is strain specific character. It is clear that bacteriocin production may play an important role in interspecific competition. These strains may help in the improvement of legume inoculants.

\section{Acknowledgements}

The first author (EP) is grateful to University Grants Commission, New Delhi for financial assistance in the form of Rajiv Gandhi National Senior Research Fellowship (RGNSRF). 


\section{References}

1. Bromfield ESP, Sinha IB and Wolynetz MS. 1986. Influence of location, host cultivar and inoculation on the composition of naturalized population of Rhizobium meliloti in Medicago sativa nodules. Appl Environ Microbiol. 51: 1077-1084.

2. Singleton PW and Tavares JW. 1986. Inocoulation response of legumes in relation to number and effectiveness of indigenous population. Appl Environ Microbiol. 51: 1013-1018.

3. Perveen N, Chauhan S and Gaur YD. 1987. Antigenic relationship among bacteriocin producing and non-producing strains of Cajanusrhizobia. Current Science. 56: 611-615.

4. Schwinghamer EA. 1971. Antagonism between strains of Rhizobium trifolii in culture. Soil Biol Biochem. 3: 355-363.

5. Oresnik IJ, Twelker S and Hynes MF. 1999. Cloning and characterization of Rhizobium leguminosarum gene encoding a bacteriocin with similarities to TRX toxin. Appl Environ Microbiol. 65: $2833-2840$

6. Tagg JR, Dajami A and Wannanaker LW. 1976. Bacteriocins of gram positive bacteria. Bacterial Reviews; 40: 722-756.

7. Hirsch PR. 1979. Plasmid determined bacteriocin production by Rhizobium leguminosarum. J Gen Microbiol. 113: 219-228.

8. Schwinghamer EA and Brockwell J. 1978. Competitive advantage of bacteriocin and phage like bacteriocin of Rhizobium trifolii. Can J Microbiol. 19: 359-368.

9. Van-Brussel AAN, Zaat SAAJ, Wijffelman CA, Pees E and Lugtenberg BJJ. 1985. Small bacteriocins of fast growing rhizobia are chloroform soluble and is not required for active nodulation. Journal of Bacteriology; 162: 1079-1082.

10. Higashi S. 1967. Transfer of clover infectivity of Rhizobium trifolii to Rhizobium phaseoli as mediated by an episomic factor. $J$ Gen Appl Microbiol. 13: 391-403.

11. Dunican LK, Gara O'F and Tierney AB. 1976. Plasmid control of effectiveness of Rhizobium transfer of nitrogen fixing genes on a plasmid from Rhizobium trifolii to Klebsiella aerogenes. In: symbiotic Nitrogen Fixation in Plants, International Biological Programme,Edited by P.S. Nutman. Cambridge University Press. Vol.7, pp. $77-90$

12. Johnston AWB, Beynon JL, Buchannan-Woliaston AV, Setchell SM., Hirsch PR and Beringer JE. 1978. High frequency transfer of nodulating ability between strains and species of Rhizobium. Nature. 276: $635-636$.

13. Hardy KG. 1975. Colinogeny and related phenomena. Bacterial Reviews. 39: 464-515.
14. Roslycky EB. 1967. Bacteriocin production in the rhizobia bacteria. Can J Microbiol. 13: 431-432.

15. Lotz W and Mayer F. 1972. Isolation and characterization of a bacteriophage tail like bacteriocin from a strain of Rhizobium. $J$ Virology. 9: 160-173.

16. Schwinghamer EA. 1975. Properties of some bacteriocins produced by Rhizobium trifolii. J Gen Microbiol. 91: 403-413.

17. Vincent JM. 1970. A manual for the practical study of root nodule bacteria. IBP Hand book 15. Blackwell scientific publications Ltd. Oxford.

18. Weller DM and Cook RJ. 1989. Suppression of take-gall of wheat by seed treatment with fluorescent Pseudomonods. Phytopathology. 73: 463-469.

19. Barefoot SF and Klaenhammer TR. 1983. Detection and activity of Lactacin B, a bacteriocin produced by Lactobacillus acidophilus. Appl Environ Microbiol. 45: 1808-1815.

20. Yang R, Johnson MC. and Ray B. 1992. Novel method to extract large amount of bacteriocin from lactic acid bacteria. Appl Environ Microbiol. 58: 3355-3359.

21. Thimmaiah SK. 1999. Estimation of soluble protein by dye-binding Methods (Bradford's Method). In: Standard Methods of Biochemical Analysis, Kalyani Publishers, New Delhi, pp. 97.

22. Laemmli UK. 1970. Cleavage of structural proteins during the assembly of head bacteriophage T4. Blackwell Scientific publications Ltd. Oxford.

23. Sambrook J and Russell D. (eds). 2001. Preparation of plasmid DNA by alkaline lysis with SDS. Vol. 1 In: Molecular Cloning. By Cold Spring Harbor. New York, pp. 1.31-1.34.

24. Ahlawat OP and Dadarwal KR. 1996. Dadarwal. Bacteriocin production by Rhizobium sp. Cicer and its role in nodule competence. Soil Biol Biochem. 20: 509-515.

25. Nirmala J and Gaur YD. 2000. Detection of bacteriocinogenic strains of Cicer-Rhizobium by modified simultaneous antagonism method. Current Science. 79: 287- 288.

26. Kim MH, Kong YJ, Bock H and Hyum HH. 2006. Optimization of culture conditions and medium composition for the production of microccoccin GO5 by Microccus sp.GO5. Journal of Biotechnol.. 121: $54-61$

27. Hafeez FY, Naeem FI, Naeem R, Zaidi RH and Malik KA. 2005. Symbiotic effectiveness and bacteriocin production by Rhizobium leguminosarum bv. viciae isolated from agriculture soils in Faisalabad. Environ Experimental Botany. 54: 142- 147. 